\title{
THE IMPACT OF PHYSICAL ACTIVITY IN THE 'KEEP YOUR BODY STRAIGHT' PROGRAM ON THE SELECTED FEATURES OF BODY POSTURE IN SAGITTAL PLANE IN CHILDREN AGED 7-9 YEARS
}

\author{
WPŁYW WYSIŁKU FIZYCZNEGO STOSOWANEGO W RAMACH PROGRAMU \\ „TRZYMAJ SIE PROSTO” NA WYBRANE CECHY POSTAWY CIAŁA \\ W PŁASZCZYŹNIE STRZAŁKOWEJ DZIECI W WIEKU 7-9 LAT
}

\author{
${ }^{1}$ Social Academy of Sciences, 47 Kościuszki Str., Szczecinek \\ ${ }^{2}$ Kazimierz Wielki University, Institute of Physical Culture, Bydgoszcz \\ ${ }^{3}$ Kręg-Clinic, 192 Strzeszyńska Str., Poznań
}

Su m mary

\begin{abstract}
Increasing attention is being paid to health and healthcare of pupils in Polish schools.

The aim of the study was determining the impact of physical activity in the correction 'Keep your body straight' program on incorrect body postures in children aged 7-9 years.

The study included 1864 children. The children participated in corrective activities within the 'Keep your body straight' program. Methodology of carrying out the analysis involved the measurement of physiological spinal curvatures and torso verticality in the habitual posture using a photogrammetric method in six half-year editions under the 3-year research program. Gender-based differences are statistically insignificant as regards: the inclination angle of the thoracic-lumbar spine (Beta) and the upper thoracic spine (Gamma), depth of lumbar lordosis (GLL-), depth of thoracic kyphosis (GKP), thoracic kyphosis length (DKP), height (RKP) and angle (KKP), lumbar lordosis length (DLL), height (RLL) and angle (KLL), torso flexion angle (KPT-).
\end{abstract}

Statistically significant differences concerned: the inclination angle of the lumbar-sacral spine (Alfa), the sum of partial angles Delta (Alfa, Beta, Gamma) and torso extension angle (KPT).

Conclusions

1. Corrective activities in the 'Keep your body straight' program combined with education of parents are effective means in the correction process of body postures concerning physiological spinal curvatures in children aged 7-9 years.

2. Physical activity applied within the program significantly influenced all the features describing lumbar lordosis, thoracic kyphosis and trunk verticality.

3. The effectiveness of the program can be enhanced by an individual approach to every 'incorrect' posture in a child, which could not be achieved due to insufficient school funds.
W polskich szkołach coraz więcej uwagi poświęca się problematyce zdrowia i opieki zdrowotnej ucznia.

Określenie wpływu wysiłku fizycznego w ramach programu korekcyjnego „Trzymaj się prosto” na błędy postawy ciała 7-9 letnich dzieci.
Badaniami objęto 1864 dzieci. Dzieci uczestniczyły w programowych zajęciach korekcyjnych „Trzymaj się prosto". Metodyka badań obejmowała pomiar metodą fotogrametryczną strzałkowych krzywizn fizjologicznych kręgosłupa i wertykalności tułowia w postawie habitualnej w 6 edycjach 3-letniego programu badawczego. 
Różnice międzypłciowe są statystycznie nieistotne w: kącie nachylenia odcinka piersiowo-lędźwiowego (Beta) i piersiowego górnego (Gamma), głębokości lordozy lędźwiowej (GLL-), głębokości kifozy piersiowej (GKP), długości (DKP), wysokości (RKP) i kącie kifozy piersiowej (KKP), długości (DLL), wysokości (RLL) i kącie (KLL) lordozy lędźwiowej, kącie zgięcia tułowia (KPT-). Natomiast statystycznie istotnie: kącie nachylenia odcinka lędźwiowokrzyżowego kręgosłupa (Alfa), sumy kątów cząstkowych Delta (Alfa, Beta, Gamma) i kącie wyprostu tułowia (KPT).
W n i o s k i

1. Zastosowany program ćwiczeń korekcyjnych „Trzymaj się prosto” połączony z edukacją rodziców jest skutecznym środkiem w procesie naprawczym postawy ciała dzieci w obrębie krzywizn fizjologicznych kręgosłupa w wieku od 7 do 9 lat.

2. Zastosowany wysiłek fizyczny wpłynął w znaczącym stopniu na wszystkie cech opisujące lordozę lędźwiową, kifozę piersiową i wertykalność tułowia.

3. Efektywność programu można zwielokrotnić, indywidualnym podejściem do każdej „błędliwej” postawy dziecka, czego nie udało się zrealizować ze względu ograniczone środki finansowe szkoły.

Key words: posture defects, correction, compensation, physical effort

Stowa kluczowe: wady postawy, korekcja, kompensacja, wysiłek fizyczny

\section{INTRODUCTION}

Increasing attention is being paid to health and healthcare of pupils in Polish schools. Health promoting programs have been developed as reflected in numerous publications $[1,2,3,4]$. The main causes of most health problems in children and teenagers include incorrect health behaviors and adverse effects of their socioeconomic environment (mainly home environment). According to the studies, $77 \%$ of teenagers spend more than 2 hours a day watching television, whereas $44 \%$ of boys and $31 \%$ of girls as much as 4 hours on a daily basis [3]. The research carried out in 1978-1980 among pupils in classes I-IV of primary schools in the Southeast Macroregion showed better physical condition of children from rural areas and small towns in comparison to children from big cities, while the level of somatic development of children from cities was higher when compared to their rural counterparts. Different environmental characteristics could be clearly observed in development of Polish children. This particularly referred to strength, agility and speed, which could be observed particularly among girls [6]. As it results from surveys, about one third of 25 European schools of higher education which responded to the survey sent to them, conduct corrective activities, that is, in Belgium: University of Leuven, the Netherlands: universities in Eindhoven and Nijmegen, Germany: universities in Hamburg, Essen, Hannover, Sweden: Uppsala University and University of Gothenburg, Hungary: University of Goddollo. Polish universities did not respond to the survey, nor did the British and French ones [7].

Abnormal sagittal curvatures comprise a complex problem just like all asymmetries in frontal and vertical planes. This could be treated as one of local environ- mental impacts. Still, the prevalence of these issues, especially within thoracic kyphosis and lumbar lordosis, makes one wonder about efficiency of physical activity during school corrective exercises in the program and during PE classes. Own scientific studies have shown [8] that these activities do not meet the expected requirements. Therefore, basic functions of physical education including stimulation, adaptation, compensation, correction and such purposes as maintaining the natural motility of children and youth, improving physical activity, developing talents in physical activity and managing the development of movement features are not fulfilled. Krawański [9] reports that body posture stimulants consist of: postural development and efficiency of skeletal muscles, maintaining the optimal volume of joint movement and preserving the upright position reflex.

The purpose of the study is to determine the impact of physical activity in the correction 'Keep your body straight' program on incorrect body postures in children aged 7-9 years.

\section{MATERIAL, METHODS AND SUBJECT}

The research program was implemented in $2007-$ 2010. The first edition included first class pupils from 21 randomly chosen primary schools from the Warmińsko - Mazurskie region. The study group was regarded as homogenous in terms of their place of residence as dividing children into groups from cities and rural areas would be improper and this characteristic would never determine the homogenous character of the group. From among all children qualified by a school doctor, the measurements covered those who had been diagnosed improper body postures using Postorumeter M. Eventually the study 
included 1864 children (977 girls and 887 boys). Test results of girls from class I -322 , II -383 , III -272 were eligible for the purpose of analysis and in case of boys: $316,325,246$, respectively. The average body weight of girls aged 7 was $26.42 \mathrm{~kg}$ and their average height was $121.0 \mathrm{~cm}$. The 8 -year old girls' average weight was $26.42 \mathrm{~kg}$ and height: $128.28 \mathrm{~cm}$ and for 9-year old girls these were $30.14 \mathrm{~kg}$ and $132.87 \mathrm{~cm}$, respectively. As far as boys are concerned, the average weight at the age of 7 was $23.21 \mathrm{~kg}$ and height: 127.93 $\mathrm{cm}$. For age 8 , these were $28.0 \mathrm{~kg}$ and $130.23 \mathrm{~cm}$, respectively and for age 9: $31.34 \mathrm{~kg}$ and $134.47 \mathrm{~cm}$, see Figure 1. The children participated in the corrective activities into which a pro-health program 'Keep your body straight' was implemented [10].

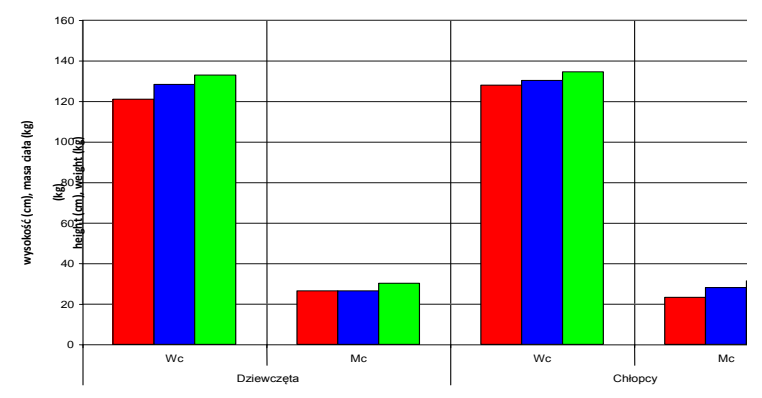

Fig. 1. Average height and mass in girls and boys aged 7-9 years. $n: D z .=977, C h .=887$

Ryc. 1. Średnie wielkości wysokości i masy ciała dziewcząt i chłopców $w$ wieku 7-9 lat. $n: D z .=977$, Ch. $=887$

Table 1. The list of measured habitual postural features in sagittal plane

\begin{tabular}{|c|c|c|c|c|}
\hline \multirow[t]{2}{*}{ No. } & \multicolumn{4}{|c|}{ Features } \\
\hline & Symbol & $\begin{array}{c}\text { Measurement } \\
\text { unit }\end{array}$ & Name & Description \\
\hline 1 & Alfa & \begin{tabular}{|l|l} 
Degrees & \\
\end{tabular} & \multicolumn{2}{|c|}{ Inclination angle of the lumbar-sacral spine } \\
\hline 2 & Beta & Degrees & \multicolumn{2}{|c|}{ Inclination angle of the thoracic-lumbar spine } \\
\hline 3 & Gamma & Degrees & \multicolumn{2}{|c|}{ Inclination angle of the upper thoracic spine } \\
\hline 4 & Delta & Degrees & \begin{tabular}{|l|}
$\begin{array}{l}\text { Sum of angle } \\
\text { values }\end{array}$ \\
\end{tabular} & Delta = Alfa + Beta + Gamma \\
\hline 5 & KPT & Degrees & $\begin{array}{|ll|}\begin{array}{l}\text { Torso } \\
\text { angle }\end{array} & \text { extension } \\
\end{array}$ & \multirow{2}{*}{$\begin{array}{l}\text { Expressed by the deviation of } \\
\text { the C7-S1 line from the vertical }\end{array}$} \\
\hline 6 & KPT - & Degrees & \begin{tabular}{|l|l|}
$\begin{array}{l}\text { Torso } \\
\text { angle }\end{array}$ & flexion \\
\end{tabular} & \\
\hline 7 & DKP & $\mathrm{Mm}$ & \begin{tabular}{|l|} 
Length of \\
thoracic kyphosis
\end{tabular} & $\begin{array}{l}\text { Distance between points C7 } \\
\text { and LL }\end{array}$ \\
\hline 8 & KKP & Degrees & \begin{tabular}{|l|} 
Thoracic \\
kyphosis angle
\end{tabular} & KKP $=180-($ Beta + Gamma $)$ \\
\hline 9 & RKP & $\mathrm{Mm}$ & $\begin{array}{l}\text { Thoracic } \\
\text { kyphosis height }\end{array}$ & $\begin{array}{l}\text { Distance between points C7 } \\
\text { and PL }\end{array}$ \\
\hline 10 & GKP & $\mathrm{Mm}$ & $\begin{array}{l}\text { Thoracic } \\
\text { kyphosis depth }\end{array}$ & $\begin{array}{l}\text { Horizontal distance between } \\
\text { vertical lines passing through } \\
\text { points PL and KP, at the level } \\
\text { of point KP }\end{array}$ \\
\hline 11 & DLL & $\mathrm{Mm}$ & \begin{tabular}{|l|}
$\begin{array}{l}\text { Lumbar lordosis } \\
\text { length }\end{array}$ \\
\end{tabular} & \begin{tabular}{|l}
$\begin{array}{l}\text { Distance between points KP } \\
\text { and S1 }\end{array}$ \\
\end{tabular} \\
\hline 12 & KLL & Degrees & 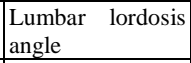 & KLL $=180-($ Alfa + Beta $)$ \\
\hline 13 & RLL & $\mathrm{Mm}$ & \begin{tabular}{|l|}
$\begin{array}{l}\text { Lumbar lordosis } \\
\text { height }\end{array}$ \\
\end{tabular} & $\begin{array}{l}\text { Distance between points PL } \\
\text { and S1 }\end{array}$ \\
\hline 14 & GLL - & $\mathrm{Mm}$ & 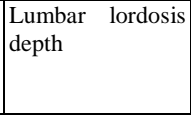 & $\begin{array}{l}\text { Horizontal distance between } \\
\text { vertical lines passing through } \\
\text { points PL and LL, at the level } \\
\text { of point LL }\end{array}$ \\
\hline
\end{tabular}

Source: own study
Methodology of carried out analysis involved the measurement of the selected features of physiological spinal curvatures in the habitual posture, Table 1 . In order to assess the value of the selected sagittal features of the axial locomotor system a photogrammetric method was used. The study methods and technique were in line with the principles established [11].

The results obtained in a form of spatial and graphic images ensured a numerical description of the features investigated.

\section{CONCLUSIONS}

The results of measurements from all six half-year editions in the 3-year research program were subjected to statistical analysis, table 2, 3. Empirical data were quantitative features. They were presented in the description as the arithmetical mean and standard deviation. The set of features revealed a normal distribution, which is why proper parametric tests were used for the purpose of further calculations. To ensure determining of the mutual statistical relationship between features, linear correlation coefficients were calculated by means of the Person test. Significant statistical differences were assesses using the twofactor test ANOVA with repetitions, then the post hoc Tukey's test was applied. The analysis of differences was performed using t-Student tests in the Welch modification, the variation uniformity was assessed with F- Fischer tests and F - Snedecor tests. Required statistical calculations were performed using the program Statistica StatSoft, Inc. (2005). STATISTICA (data analysis software system), version 6.3 www. statsoft. lic. no. AXAP311B316618AR.

The research has shown that physical activity applied within the program 'Keep your body straight' has a significantly positive and corrective influence on all the analyzed postural features. Gender-based differences are statistically insignificant as regards: the inclination angle of the thoracic-lumbar spine (Beta) and the upper thoracic spine (Gamma), depth of lumbar lordosis (GLL-), depth of thoracic kyphosis (GKP), thoracic kyphosis length (DKP), height (RKP) and angle (KKP), lumbar lordosis length (DLL), height (RLL) and angle (KLL), torso flexion angle (KPT-). Statistically significant differences concerned: the inclination angle of the lumbar-sacral spine (Alfa), the sum of partial angles Delta (Alfa, Beta, Gamma) and torso extension angle (KPT). the progression of the 


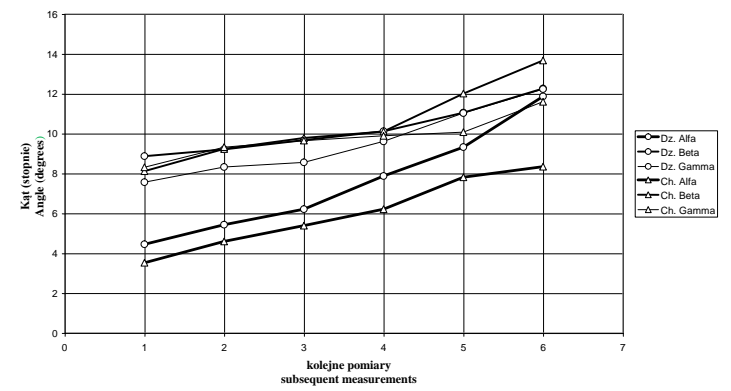

Fig. 2. Average partial angles Alfa, Beta, Gamma in girls and boys aged 7-9 years. $n: D z .=977, C h .=887$

Ryc. 2. Średnie wielkości kątów cząstkowych Alfa, Beta, Gamma dziewcząt $i$ chłopców $w$ wieku 7-9. lat $n=D z .977$, Ch. 887

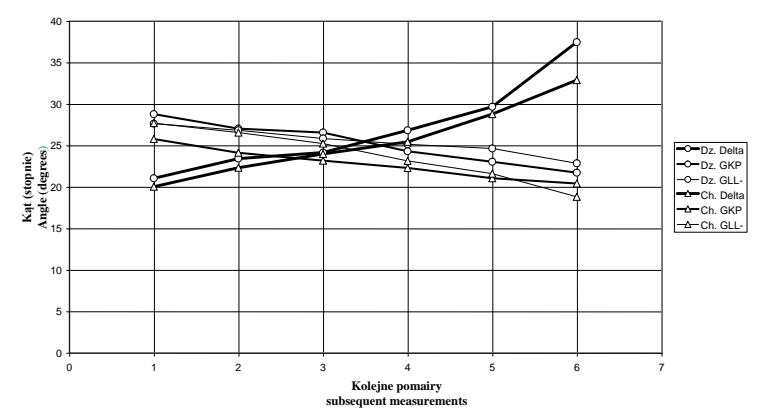

Fig. 3. Average sum of partial angles Delta, GLL- and GKP in girls and boys aged 7-9 years. $n: D z .=977, C h$. $=887$

Ryc. 3. Średnie wielkości sumy kątów cząstkowych Delta, GLL- $i$ GKP dziewcząt $i$ chtopców w wieku 7-9 lat $n: D z .=977, C h .=887$

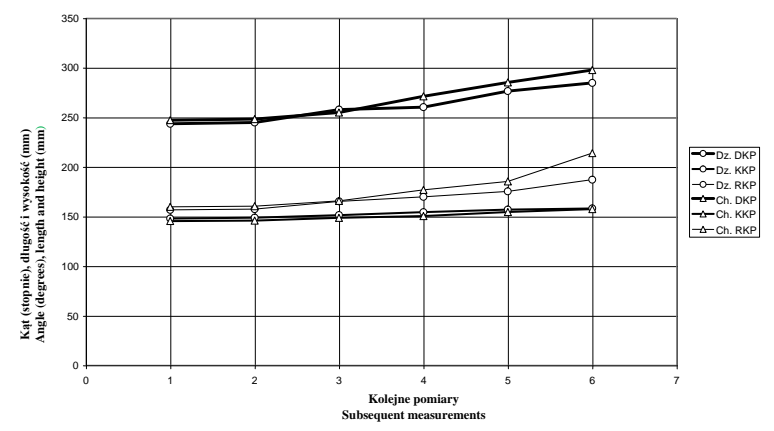

Fig.4. Average values of DKP, KKP and RKP in girls and boys aged 7-9 years. $n: D z .=977, C h .=887$

Ryc. 4. Średnie wiekości DKP, KKP $i$ RKP dziewcząt i chłopców $w$ wieku 7-9 lat. $n:$ Dz. $=977$, Ch. $=887$

inclination angle of the lumbar-sacral spine (Alfa), the thoracic-lumbar spine (Beta) and the upper thoracic spine (Gamma) were successively corrected obtaining optimal values as observed in the boys involved in the study; however, the group of girls showed that the Alfa angle assumed statistically significant larger values in comparison to boys and closer the upper limit of normal range. A similar tendency can be observed in case of the distribution of Delta feature values, being the sum of partial angles (Alfa+Beta+Gamma). The angle (KLL) and depth (GLL-) of lumbar lordosis also assumed the values close to the lower limit of normal range. Therefore, it seems that higher values of the torso extension angle (KPT) are a biomechanical consequence of determined values.

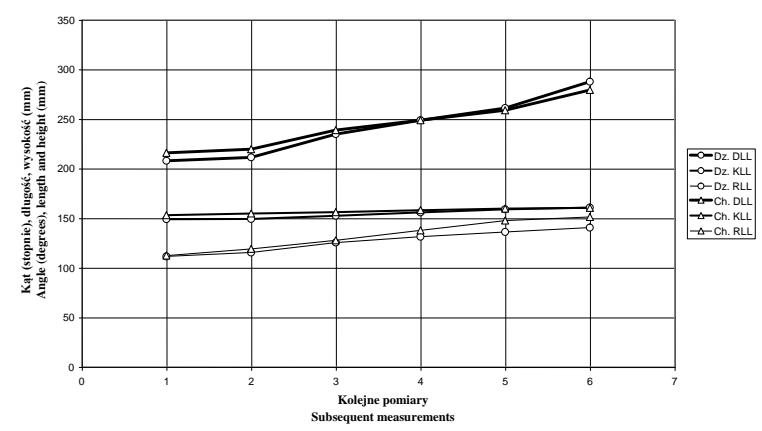

Ryc. 5. Średnie wielkości DLL, KLL i RLL dziewcząt $i$ chłopców $w$ wieku 7-9 lat. $n: D z .=997$, Ch. $=887$

Fig. 5. Average values of DLL, KLL and RLL in girls and boys aged $7-9$ years. $n: D z .=977, C h .=887$

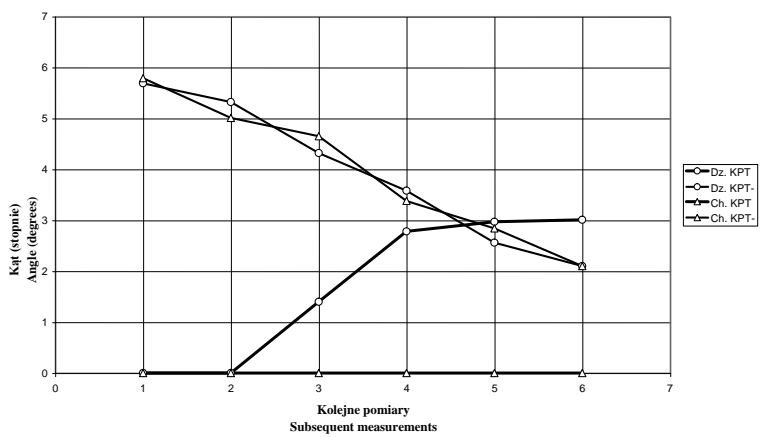

Fig. 6. Average values of KPT, KPT- in girls and boys aged 7-9 years. $n: D z .=977, C h .=887$

Ryc. 6. Średnie wielkości KPT, KPT-dziewcząt i chłopców w wieku 7-9 lat. $n: D z .=977, C h .=887$

\section{DISCOURSE}

The analysis of body posture by means of a photogrammetric method in 22 boys, half of whom from a general education class and others from a sports class, revealed a less proper body posture in boys from a general education class as shown in the measurement results: torso inclination angle $-5.46^{\circ}$, lumbar lordosis angle $-168.92^{\circ}$, thoracic kyphosis angle $-157.46^{\circ}$, compensation index -10.09 , thoracic kyphosis depth $9.01 \mathrm{~mm}$, torso inclination angle $-2.83^{\circ}$, pelvic inclination angle $-1.45 \mathrm{~mm}$, maximal deviation of the 
spinal line C7-S1 from the straight: $6.27 \mathrm{~mm}$ [14]. Weber [15, 16] believes that physical exercise focused on body posture correction cannot influence structural changes or bone growth.

The central European model appears to be more logical as opposed to the American system in terms of using corrective exercises at schools. However, the whole point of these exercises is that they should be effective. It has been found that the time preceding the first menstrual period in girls and mutation in boys is a critical moment in preventive therapy $[17,18,19,20]$. Hence, corrective exercises to straighten posture, performed during that period, reduce a thoracic kyphosis, increase a lumbar lordosis and, in consequence, lead to increased rotation and subsequent progression of postural curvature with scoliotic changes. Despite a number of methods and varieties in therapeutic procedures, the treatment of scoliosis still poses a basic problem for physiotherapists, rehabilitants, physical education teachers and corrective gymnastics teachers. Depending on the view of the complex process of scoliosis-related changes, it is recommended to conduct either symmetric exercises or exclusively asymmetric exercises [21, 22]. Malawski [23] and Karski [24] emphasize that improper exercises are used in order to strengthen long dorsal muscles running along the scoliosis chord and causing an auxotonic pressure on the curvature which can strengthen hypertonic tension of soft tissue affected by scoliosis. Torell [25] reported that early therapy using focused exercises preceded by early diagnosis leads to reduced occurrence of scoliosis above 40 degrees by $63 \%$. It is necessary to establish a system of corrective actions based on appropriately trained staff and a transparent system of eligibility for correction groups, assuming diverse groups in terms of postural defects. It is required to promote and indicate the direction of reasonably taken correction so that to increase its effectiveness and efficiency [26].

\section{CONCLUSIONS}

1. Corrective activities within the 'Keep your body straight' program combined with education of parents are effective means in the correction process of body postures concerning physiological spinal curvatures in children aged 7-9 years.

2. Physical activity applied within the program significantly influenced all the features describing lumbar lordosis, thoracic kyphosis and trunk verticality.

3. The effectiveness of the program can be enhanced by an individual approach to every 'incorrect' posture in a child, which could not be achieved due to insufficient school funds. 


\section{REFERENCES}

1. Błażejewski Z., Health education - important and urgent tasks. New School, 1991; 3: 8-12.

2. Gniewkowski W., Health promotion. School's Life, 1988; 5, 34-38

3. Woynarowska B., How to promote health, Educational Health Issues, 1996; 6, 15-20.

4. Bendíkova E., Uvinha, R. R., Marko, M., Pain as manifestation of functional disorders of musculoskeletal system. Sport Science 9, 2016; 1: 90-95.

5. Bendíková, E., Pavlović, R., Impact of the exercise programme based on Flowin concept and implemented in physical and sports education classes on functions of the postural muscle system. In Sport scientific and practical aspects : international scientific journal of kinesiology. - Tuzla : Tuzla university, Faculty of physical education and sport, 2013; Vol. 10, 2, 25-33.

6. Report of the Committee of Experts, Health of children and adolescents in education. New School, 1990; 4, 36-43.

7. General Board of AZS, European debate on: Physical education of students in European universities under II Assembly of Academic Physical Culture in Szczecin. 2004.

8. Mrozkowiak M., Effectiveness of physical exercise under the program of postural correction activities in children aged 7-9 years in selected primary schools from the Warmińsko-Mazurskie region, [in] Pęczkowski [ed.], Polish System of Education after the reform in 1999, II International Scientific Conference: Education of the $21^{\text {st }}$ century, Piła. 2004; 236- 244.

9. Krawański A., Process of body posture formation from a systemic perspective, [in] Spinal dysfunctions diagnosis and therapy [ed.] Nowotny J., AWF Katowice, 1993; 125-135.

10. Mrozkowiak M., Concept of school correction - Club "Keep your body straight", [in] Pęczkowski [ed.], Polish System of Education after the reform in 1999, II International Scientific Conference: Education of the $21^{\text {st }}$ century, Piła, 2004; 236- 244.

11. Mrozkowiak M., Strzecha M., Mora projection as a contemporary diagnostic tool for assessing body posture, Anthropomotoric aspects, 2012; Vol. 22; 60, 33-49.

12. Mrozkowiak M., Modulation, impact and relations of selected parameters of body posture in children and adolescents aged 4 to 18 years in the light of mora projection, University of Kazimierz Wielki, Bydgoszcz, Vol. II, 2015.

13. Wilczyński J., Differences in body posture between 14-year old boys from general education and sports classes. Physical and Health Education, 2004; 1, 13-17.

14. Kotwicki T. et al., Pathomechanics of idiopathic scoliosis from a three plane perspective and the consequences for the choice of corrective exercises in children with scoliosis. Rehabilitation Progress, 2001; 15, 3, 47-48.

15. Weber M., Entwicklung und Effektivitat der krankengymnastischen Behandlung der Skoliose. Krankengymnastik, 1985; 37, 11, 743-748.
16. Weber M., Hirsch S., Krankengymnastik bei idiopathischer Skoliose. Gustav Fischer Verlag, Stuttgart, 1986.

17. Dobosiewicz K., Lateral idiopathic curves, Silesian Medical University, Katowice, 1997.

18. Kotwicki T., et al., Impact of exercise on idiopathic scoliosis - proposal of multi-environmental research. Rehabilitation Progress, 2002; 16, Supplement 3.

19. Kotwicki T. et al., Pathomechanics of idiopathic scoliosis from a three plane perspective and the consequences for the choice of corrective exercises in children with scoliosis. Rehabilitation Progress, 2001, 15, 3, pp. 47-48.

20. Łubkowska W., 2003, Assessment of physiological spinal curves and its significance in the practice of school physical education, In: Doctoral Dissertation, Gdańsk, 2003.

21. Lubkowska W., The Concept of Scoliosis Treatment applying Asymmetrical Aquatic Exercises. Central European Journal of Sport Sciences and Medicine, 2015; 9 (1), 1-10.

22. Bendíková, E., Stackeová, D., Effect of exercise programme with compensatory aim targeting on spine mobility in school girls of secondary high school. In Hygiena : časopis pro ochranu a podporu zdraví. - Praha : Státní zdravotní ústav, 2015; 1, 4-9.

23. Malawski S., Own principles of low degree scoliosis treatment in the light of contemporary views on etiology and pathogenesis of scoliosis. Musculoskeletal Surgery and Polish Orthopedics, 1994; LIX, 3, 189-197.

24. Karski T., Coxa and pelvic contractures and growth disorders as the cause of development of the so called "idiopathic scoliosis". Biomechanical deliberations. Musculoskeletal Surgery and Polish Orthopedics, 1996; Vol. LXI, 2., 143-150.

25. Torell G. et al., 1981, The Changing pattern of scoliosis treatment due to effective screening. Journal of Bone and Joints Surgery, 1981; 63A, p. 337.

26. Łubkowska W., Zdeb T., Mroczek B., Assessment of development of physiological spinal curves in girls who train and do not train swimming. Family Medicine \& Primary Care Review, 2015; 17(3), 185-188.

Address for correspondence:

e-mail: magmar54@interia.pl

Received: 20.07.2016

Accepted for publication: 12.08 .2016 